logist. It has been a centre of human habitation from the stone age onward and is one of the principal centres in Great Britain of the civilisation of the early bronze age, when it appears to have been thickly populated. In addition to the evidence of stone circles, round barrows and other monuments in the area, the culture of the district is to be studied in the rich and varied collections of funerary pottery, implements, weapons and ornaments of stone and bronze, which are to be seen in the museums of Buxton, Derby and Sheffield. Mr. Holmes, in addition to this generous gift, has shown his interest in the preservation of the antiquities and natural beauties of his county by his association with the efforts which secured the other Derbyshire properties for the nation, as well as by his work as chairman of the Buxton Committee of the Council for the Preservation of Rural England.

\section{Stenhouse Williams Memorial Library}

ON Saturday, October 13, the library erected at the National Institute for Research in Dairying (University of Reading), to the memory of the first director of the Institute, Dr. R. Stenhouse Williams, was opened by the Minister of Health, the Right Hon. Sir E. Hilton Young, in the presence of numerous guests, presided over by the chairman of the Board of the Institute, the Earl of Iveagh, and including subscribers to the memorial fund, members of the University of Reading, and others directly interested in dairy science or the Institute. Sir Hilton Young said that it was particularly gratifying to him as H.M. Minister of Health to assist in celebrating this step forward in the development of one of the most essential health services. Milk has a unique place in the dietary of the people, and although its consumption is relatively low, there has been in recent years an increasing understanding by the public of the value of milk in nutrition. He emphasised the importance of research in increasing the consumption of milk and improving the methods of production, and paid a tribute to the great pioneering activities of Dr. Stenhouse Williams in the field of dairy research, and in the development of the Institute. A library is an absolutely essential part of the Institute. Its foundation is, however, but a beginning : it needs not only the original but also the continued benevolence of the community. All present would remember with gratitude those who have combined to bring this memorial into existence in so appropriate and so efficient a form, and particularly they would think of the man who would continue to be an inspiration to those who came after him. It was stated that the Library building has cost approximately $£ 3,000$ and that present contributions to the memorial fund amount to $£ 2,300$.

\section{The Maison de la Chimie in Paris}

THE opening of the Maison de la Chimie on October 20 in Paris marks the completion of the first step towards a comprehensive scheme of centralisation of chemical bibliography and other scientific activities.
The Maison de la Chimie had its origin in the celebration of the centenary of Marcelin Berthelot in 1927, when a sum of twenty-five million francs was collected by international subscription. The French Government presented a historic building - the house of La Rochefoucauld — d'Estissac, rue St. Dominique, near the Chamber of Deputies. This has been reconstructed and extended to house a library equipped with the latest facilities. Large halls for meetings of scientific societies and congresses have also been provided. Indeed, this is a special feature of the project, and the opening of the building by $M$. Lebrun, President of the Republic, is to be followed by the holding therein of the fourteenth Congress of Industrial Chemistry (October 21-27). M. Jean Gerard, administrator of the Maison de la Chimie and Secretary of the International Union of Pure and Applied Chemistry, hopes to develop the present centre into a "Maison de la Science" where international congresses in all scientific fields can meet and be assured of the services of a staff accustomed. to the organisation of congresses. All those who have attended international gatherings know that the standard of efficiency with which they are run varies considerably, and that a little more attention paid to the purely technical part of their organisation would often add considerably to their scientific value. We may therefore wish M. Gerard all the success that his plans deserve.

\section{Iraq Oil reaches Haifa}

THE construction of the Iraq Petroleum Company's pipe-line to convey oil from the Mosul oilfields to the Mediterranean seaboard is an engineering feat of no mean importance and one which has been watched with keen interest by petroleum technologists and engineers all over the world. Its real completion may be said to have been achieved at 2.30 a.m. on October 14, when the first stream of oil pumped from the fields reached Haifa; according to the Times it is anticipated that the first shipments of oil will be made before the end of October. The pipe-line stretches for nearly 1,200 miles over extremely difficult country, much of which is desert. It runs from Kirkuk to Haditha, where it bifurcates, and the southern (British) line follows through Transjordania and reaches the pipe-line terminal at Haifa. The actual pipe-line was completed in 1933, since when most of the engineering work has been concerned with the installation of the necessary boosting stations en route. With the delivery of oil to the seaboard, it may be confidently asserted that the pumping installations have proved their efficiency and that the regular flow of oil will now become a routine matter. We have as yet no information as to whether oil is being diverted along the French line, that is, through Syrian territory to Tripolis, but doubtless this will also soon be an accomplished feat. The influence of this oil now made available to European refineries will be considerable, and will undoubtedly affect both the political and economic aspects of the petroleum industry within a com. paratively short space of time. 